\title{
Learning Styles and Development of Cognitive Skills in Mathematics Learning
}

\author{
Tatiana S. Sheromova ${ }^{1 *}$, Anvar N. Khuziakhmetov ${ }^{2}$, Victor A. Kazinets ${ }^{3}$, Zhanna M. Sizova ${ }^{4}$, \\ Stanislav I. Buslaev ${ }^{5}$, Ekaterina A. Borodianskaia ${ }^{6}$ \\ 1 Vyatka State University, Kirov, RUSSIA \\ ${ }^{2}$ Kazan (Volga region) Federal University, Kazan, RUSSIA \\ ${ }^{3}$ Pacific State University, Khabarovsk, RUSSIA \\ ${ }^{4}$ I.M. Sechenov First Moscow State Medical University (Sechenov University), Moscow, RUSSIA \\ ${ }^{5}$ Financial University under the Government of the Russian Federation, Moscow, RUSSIA \\ ${ }^{6}$ Russian State Social University, Moscow, RUSSIA
}

Received 19 April 2020 - Accepted 29 July 2020

\begin{abstract}
Modern schoolchildren are the new digital generation and their preferences for working with information are based on of the dominant sensory modality which can be visual, auditory, and tactile/ kinesthetic. Therefore, to organize effective mathematics teaching it is necessary to use a personalized system of teaching techniques, instructional methods, and educational technologies taking into account the way students process information from the outside world. In light of neuropedagogy achievements and the idea of the dynamic balance, the purpose of the article is to provide evidence for the current need for taking into account the students' perceptual learning styles which reflect the nature of interhemispheric interaction in the process of cognitive learning development in mathematics learning. The article is also aimed at establishing a scientific rationale for a classification of teaching methods for development of general learning skills, logical operations, and problem solving skills in mathematics learning based on the criteria of "dominant hemisphere" and "learning style". The research methods are content analysis of scientific, educational and methodological literature to review the methods for cognitive skill development; testing the students' level of general learning skills and the level of verbal reasoning; modeling method, Google questioning of teachers from different regions of the Russian Federation, qualitative analysis of the empirical data. The scientific novelty of the study is the obtained results: empirical data in respect to personalized learning technologies used by Russian teachers; identifying the stages of cognitive skill development in mathematics learning based on the perceptual learning styles of students; establishing a scientific rationale for a classification of techniques for development of general learning skills according to the criteria of "type of learning in accordance with the dominant hemisphere"; developing the criteria for assessing cognitive skills on the basis of the students' learning styles. The theoretical significance of the study lies in its contribution to the mathematics methodology in regard to personalized learning technologies, the techniques for developing cognitive skills in mathematics learning taking into account students' learning styles and applying the ideas of neuropedagogy and the idea of the dynamic balance in teaching mathematics..
\end{abstract}

Keywords: neuropedagogy, Mathematics learning, dynamic balance, cognitive skills, perceptual learning style, teaching methods and techniques, modality, case tasks

\section{INTRODUCTION}

A modern educator should have social, cognitive, methodological, organizational and specialized subject related competencies to be able to comprehensively analyze and organize an effective educational process. The methodological competence means that the teacher is capable and ready to independently choose and apply teaching methods and techniques appropriate for the general cultural, personal and cognitive development of

(C) 2020 by the authors; licensee Modestum. This article is an open access article distributed under the terms and conditions of the Creative Commons Attribution License (http://creativecommons.org/licenses/by/4.0/). 


\section{Contribution to the literature}

- The paper describes the stages a mathematics teacher should follow in order to develop students' cognitive skills taking into account the students' learning modality.

- A classification of techniques and methods consistent with the dominant hemisphere and the learning style and aimed at developing cognitive skills of schoolchildren is worked out.

- The study suggests the procedure for assessing the level of students' cognitive skills which are a combination of general learning skills, logical reasoning skills and problem solving skills.

students (Avdeev et al., 2019). Except for having expertise in their subject, a teacher should be competent in different scientific fields such as biology, psychology, neurophysiology, and information theory. It is necessary to provide high quality education implementing individual approach in training which can allow each student to achieve success. Let us consider some of the characteristics of the teacher functions specified in the professional standard (Order of Ministry of Labor and Social Protection, 2013). The pedagogical function of a modern teacher includes the activities aimed at acquiring cognitive, communicative, and regulatory knowledge about the basic laws of child development, development stages and crises, socialization criteria, indicators for individual peculiarities of life trajectories, possible deviations, as well as the basics of psychodiagnostics. The educational function of the teacher involves activities aimed at developing students' cognitive performance, independence, initiative, creative thinking; the skills necessary to organize educational activities taking into account age, gender, and personality characteristics; as well as basic psychodidactic knowledge (Cherdymova et al., 2018; Ovsyanik et al., 2020). In the process of interacting with students, teachers develop students' cognitive skills which are a combination of general learning skills, logical reasoning, and problem solving skills; they are very important in mathematics learning.

One of the sciences that can help the teacher solve these tasks is neuropedagogy which suggests differentiated approach to learning and taking into account psychophysiological and neuropsychological characteristics of students and teachers. The term "neurodidactics" goes back to G. Preiss $(1992,1996)$ who studied the relationship between early childhood mathematics learning and brain development. Now neurodidactics is understood as part of neuropedagogy. The main task of neuropedagogy is to increase the effectiveness of training using the knowledge about the human brain. A teacher can organize the right mode of learning, create conditions to develop cognitive skills and, if necessary, manage students' behavior by making an impact on the emotional state and senses (hearing, sight, touch) of a particular student. In this regard, it is important to take into account the student's perceptual learning style which is associated both with the activity of sensors (the dominant sensory modality) and with their thinking styles.

One cannot ignore the fact that the workload of teachers at all levels of education in Russia is quite excessive. When analyzing the results of the international study of 2015 (OECD, 2015), it was revealed that the activities of teachers specified in the normative documents include solving a lot of tasks other than teaching: preparing for classes, instructional planning, correction of students' mistakes, notebook check, administrative duties, homeroom teaching, communication with parents, school duty and watching children during breaks, research support and counseling, filling out documentation, mentoring and interaction with colleagues. Some of these activities are considered to be optional in the Czech Republic, France, Germany, England; they are performed if it is determined so by schools and teachers. However, additional responsibilities prevent teachers from being systematic when taking into account individual characteristics of students. If we consider the traditional way of mathematics teaching in this perspective, we can see that school mathematics courses usually rely on reasoning with clearly defined chains of evidence; however, this instructional method does not work for all students.

As a result, there is a contradiction between the need to take into account individual characteristics of students in the process of cognitive skills development, in particular, the style of learning, i.e., perceiving and processing information, including mathematical information, and the lack of time and other resources to study and choose an educational technology, instructional methods, and training tools that contribute to solving this problem.

To resolve this contradiction, we need appropriate and accessible technologies, methods and techniques. These are, for instance, personalized learning technologies: the technology of development of the individual cognitive learning style (Galeyeva \& Morgacheva, 2015; Zyubina et al., 2019; Khairullina et al., 2019), the multi-level task technology, the case problem technology, the level differentiation technology, the style differentiation technology, and the visualization technology which are consistent with neuropedagogy ideas, and they can be applied to promote effective development of students' cognitive skills. However, the 
study "Psychological Comfort in Education in Modern Rural School" conducted by (Korshunova \& Baiborodova, 2020) in ten regions of the Russian Federation (Nizhny Novgorod, Ivanovo, Vologda, Kirov, Kostroma, Yaroslavl regions; Krasnoyarsk Krai, Perm Krai, and the Republics of Karelia and Dagestan) shows that there are certain problems in regard to using the indicated instructional technologies, as well as their elements, i.e., particular instructional methods and techniques in the system of general secondary education. Thus, taking into consideration neuropedagogy achievements and the idea of the dynamic balance, the purpose of the article is to provide evidence for the current need for taking into account the students' learning styles reflecting the nature of interhemispheric interaction in the process of cognitive skills development in mathematics learning (Akishina et al., 2017). The article is also aimed at establishing a scientific rationale for a classification of teaching methods for development of general learning skills, logical operations, and problem solving skills in mathematics learning based on the criteria of "dominant hemisphere" and "learning style".

\section{LITERATURE REVIEW}

The analysis of theoretical ideas developed in the field of neuropedagogy has identified two main research domains: brain functions in mental processing; psychological and pedagogical research devoted to testing and learning models which take into account the perceptual learning style preferences at different levels of education.

The theoretical foundations of neuropedagogy are physiology findings by Bekhterev, Pavlov, Sechenov, Anokhin, Adrian, Lashley, R.W. Sperry $(1975,1961)$, and others; psychophysiology studies by Hebb, Pribram, Golubev, Nebylitsyn, Teplov, Traugott, and others; neuropsychology studies by Luria, Mikadze, Khomskaya, Tsvetkova, and others

Sperry (1961) described the ability of the hemispheres to function independently following separation produced by transection of the corpus collosum, the nerve fiber bundle interconnecting the two hemispheres. The studies conducted by (Gazzaniga \& Sperry, 1967) led to conclusion that the left hemisphere is involved in speech and sign processing, processes information sequentially and is usually described as analytical, and the right hemisphere is responsible for non-verbal functions and the centre of intuitive thinking. The scientific achievements by Sperry (1961) were highly appreciated and he was awarded the Nobel Prize in Physiology or Medicine in 1981. However, there is no strict subdivision between the functions of the cerebral hemispheres. The experiments conducted by Posner and Raichle (1994), Dehaene (1996) showed that various parts of the brain can be activated in response to a specific task and its solution options.

Modern research into information processing in the human brain before and after doing logic puzzles is carried out with the use of functional magnetic resonance imaging (Firsova et al., 2018). Neuroscientists studying functional anatomy try to find out how specific logical operations are carried out, and what changes take place in the brain. The subjects in the experiment were offered two sets of assignments. In the first task, the answer given was based on the experience of the participants, and in the second task they had to follow the logic of learning as they were instructed to give a logical answer (Gimaliev et al., 2018; Mutavchi et al., 2018). The tomography scans from the first and second experiments showed different activation for the left inferior frontal gyrus, left middle frontal gyrus, and the cerebellum. Thus, the tomography data showed that logical learning leads to changes in brain activity associated with cognitive control. In the research on deductive reasoning by Goel (2007) the research procedure consisted of getting acquainted with the materials, creating a conflict and a situation of uncertainty for the subjects, then looking for solutions. The imaging results of Wisconsin Card Sorting Test (Goel, 2007; Prado \& Noveck, 2007) demonstrated that the right hemisphere is responsible for conflict detection and its resolution. At the same time, Goel (2015) argues that it is necessary to develop both hemispheres to successfully deal with indeterminacy in real-world problem solving. He reasonably believes that pedagogy should rely on knowledge of functional anatomy, and learning is the main factor for reorganizing the part of the nervous system involved in thinking processes. As an example, let us consider the study by Marinsek et al. (2014), who suggests that the left hemisphere specializes in creating hypotheses and representing causality, while the right hemisphere specializes in evaluating hypotheses, and rejecting those that are implausible or inconsistent with other evidence. Thus, the left and right hemispheres play distinct, yet complementary, roles in problem solving. Danyushenkov and Korshunova (2013) study schoolchildren's cognitive activity in solving physics related problems by means of computer-based electroencephalography. When comparing the integral (deductive) and differential (inductive) styles of thinking (Berulava \& Berulava), it was found that students with an integral thinking style show activation in the right side of the brain, while students with a differential style demonstrate more balanced activation amplitudes in the left side of the cerebral cortex. Bruer (1997) states in his study that cognitive science and neuroscience can provide useful insights for the science of learning and instructions, however, he is skeptical in respect to the question about the right brain versus the left brain and its applications in educational practice. 
It is necessary to take into account not only the functions of the hemispheres, but also how the learner receives and processes information from the outside world. Ananyev (1968) believed that sensory and perceptual characteristics are the basis for shaping the individual's identity and how they interact with his or her environment, therefore, underestimation of the dominant sensory system can cause difficulties in learning. Barbe and Michael (1981) believes that different modality strengths (vision, audition, and kinesthesia) should be used to improve learning. He agrees that a modality strength may occur in a single channel, but most often it is mixed, i.e., involves two or more channels, and modality strengths can change with age. Fleming and Baume (2006) suggest four types of modality: visual, aural, read/write and kinesthetic. Dunn and Dunn (1993) believed that when learners are aware of their learning style it allows them to choose more effective learning strategies, and it allows teachers to modify instructional strategies and better understand their students; if the material is presented in their preferred modality, individuals learn and remember best (Dunn, 1983; Dunn \& Dunn, 1993). Byrnes and Fox (1998) describe the benefits of incorporating cognitive neuroscience findings into the field of educational psychology and provide arguments against the idea that one can ignore the brain when positing a model of student learning. Kraitzig and Arbuthnott (2006) conducted a series of studies and made a conclusion that, apart from learning preferences, motivation and situation factors are beneficial to effective learning performance. However, taking into account the proffered modality, according to Ellerman and Kleiner (1996), allows establishing rapport and creating favourable working environment. Dalinger (2020) provides examples of visual search for solving mathematics related tasks. Pobokin (2014) believes that visual images should become a leading methodological tool to develop mathematical abilities of schoolchildren.

In the Russian Federation, studies devoted to testing and designing the models for teacher-learner interaction were carried out by Khrizman and Zaitseva (1981), Eremeeva (2010), Galeyeva and Morgacheva (2015). They believe that taking into account individual characteristics of a learner, such as the dominant hemisphere and modality, will contribute to realization of each learner's inherent potential. Khrizman and Zaitseva (1981) demonstrated that children experienced an increase in intrahemispheric and interhemispheric interactions when the emotional component was used in word perception. Galeyeva and Morgacheva (2015) considers the dominant hemisphere of the brain and modality to be the parameters of educational activity which support cognitive processes and optimize the learning process.

In the present study, we believe that a teacher should use the knowledge about the dominant brain hemisphere and the students' learning style preferences to develop their cognitive skills. To facilitate further development of these skills, it is necessary to involve the opposite hemisphere and other modalities. Thus, a teacher will be able to create conditions to optimize interhemispheric interaction and develop other sensory channels to a greater extent.

\section{RESEARCH METHODOLOGY}

\section{Theoretical Framework}

The psychophysiological mechanisms that support cognitive processes are primarily the dominant hemisphere and the modality in which perception ("delivery") of information occurs. Modality is the dominant sensory channel that is more efficient for processing information; it characterizes the perceptual learning style of an individual. As a rule, learning styles are correlated with visual, auditory, tactile/kinesthetic modalities (Barbe \& Michael, 1981).

Both hemispheres of the brain are involved in the thinking process. But the dominance of one hemisphere over the other determines different thinking and processing of information: the left hemisphere works with abstract logical information, the right hemisphere supports visual spatial processing. There are three types of interhemispheric asymmetry: a mixed type which does not demonstrate evident dominance of a particular hemisphere, left hemisphere dominance and right hemisphere dominance. Left brain dominant learners are better at logical operations, operating with numbers, formulas and other signs and symbols; they think inductively (reasoning from the particular to the general). Right-brain dominant learners process information deductively (from the general to the particular), their thinking relies on images, emotions, intuition. The studies conducted by Eremeeva (2010), Khrizman and Zaitseva (1981) demonstrate the law of neuropsychological compatibility of teachers and students. According to it, a teacher's hemispheric dominance is correlated with the subject he or she teaches, and they choose the teaching and assessment tools and practices in accordance with their modality strengths. Thus, in mathematics teaching, it is customary for teachers to rely on logical reasoning, which is directly related to the left side of the brain.

Sonier (1982) believes that teaching practices should be balanced as left oriented teaching would mean development of only left brain functions, but if we also involve right brain teaching techniques, it will be beneficial for the whole brain. However, we agree with Sperry (1975) that the right hemisphere development is paid less attention in learning than the left hemisphere development, so the teacher should create conditions to facilitate interhemispheric interaction because one should not allow isolated independent functioning of the 
Table 1. Recommended learning activities

\begin{tabular}{|c|c|}
\hline Stage & Left brain dominant learners \\
\hline Motivation Stage & $\begin{array}{l}\text { description of cognitive activity, focus on cognitive focus on the social and practical significance of the } \\
\text { motives }\end{array}$ \\
\hline Operational Stage & paying special attention to the correctness of speech \\
\hline Assessment Stage & written assessment, closed-ended questions and tasks \\
\hline
\end{tabular}

hemispheres in the process of cognitive learning. At the same time, psychologists recommend to use different activities for left- and right-hemisphere students at each stage of the educational process: motivation stage, operational stage and assessment stage (Table 1).

The expected results of the learning process are cognitive, communication, regulatory and personal skills (Asmolov et al., 2011).

Cognitive skills provide for independent learning of the surrounding environment, generalization, systematization of learning results and processing of new information. They include general learning skills: understanding and processing information delivered in different forms; extracting, structuring, modelling information using signs and symbols; logical operations: analysis, synthesis, establishing cause-and-effect links, putting forward and substantiating a hypothesis; problem solving skills: stating a problem and searching for solutions independently. Skills cannot be transferred in the ready made form or by means or demonstrating them (Galperin, 2010); they can only be learned and acquired by doing. The teacher should organize skill development activities in the following stages:

1) creating orientation basis for a certain action (explanation, demonstration and teacher's comments addressed to students);

2) skill consolidation (learners' independent practice guided by the teacher);

3) achievement testing (testing activities);

4) training a skill (practising independently to transfer an ability into a skill, i.e., an automatic action).

There are low, base, and high levels of cognitive skills.

\section{Research Methods}

The research methods are content analysis of scientific, educational and methodological literature on the methods for cognitive skill development in mathematics teaching as well as literature on sensory modality; pedagogical experiment; Stupnitskaya's diagnostics model for the level of general learning skills and the level of verbal reasoning; verbal logical reasoning test developed by Peresleni and Fotekova; "Horizontal Eight" psychological test for determining the dominant hemisphere; modelling method; Google questioning, qualitative analysis of the empirical data.

\section{Research Stages}

The study consisted of a few successive stages: the interregional study "Psychological Comfort in
Education in Modern Rural School"; training teachers to use personalized learning technologies; teaching practice aimed at development of cognitive skills taking into account the perceptual learning style of students.

A large-scale survey of teachers from different regions of Russia revealed an average level of the use of personalized learning technologies. At the next stage, the teachers of the Kirov region, Republic of Tatarstan, Moscow and Khabarovsk region schools practiced using the most requested technologies and instructional methods and techniques by discussing methodological aspects at continuing education courses (Vyatka State University, Kazan Federal University, Pacific State University, Sechenov University, Financial University under the Government of the Russian Federation, Russian State Social University) and seminars conducted in the Regional Innovation Centre of the Volgo-Vyatka Sientific and Educational Center; in the course of experimental teaching of mathematics in 5-7 grades of secondary school using the results of psychological and pedagogical diagnostics and expert observation. In the process of experimental teaching practices, the stages a mathematics teacher should follow in development of cognitive skills based on the perceptual learning styles of students were specified:

1. Psychological and pedagogical diagnostics and expert observation are carried out to determine the dominant hemisphere, perceptual learning style (modality), level of cognitive skills; a matrix of internal resources is drawn up on the basis of the obtained results. The matrix of internal resources is a table that contains the necessary data: the student's name and surname, dominant hemisphere (left, right), perceptual learning style (auditory learner, visual learner, kinesthetic learner), level (low, medium, high) of cognitive skills: general learning skills, logical reasoning skills, problem solving skills.

2. The psychological and pedagogical potential of educational activities is evaluated on the basis of the matrix of internal resources; learning activities, instructional methods matching the perceptual learning style are chosen in order to create a situation of successful learning for students. The cognitive skills are shaped at this stage. This method allows the teacher to effectively work with underperforming students and identify both psychological and subject related causes of their poor performance.

3. The forms and kinds of learning activities, instructional techniques are chosen in accordance with the matrix of internal resources to organize a situation of 
Table 2. Teacher survey results

\begin{tabular}{|c|c|c|c|c|c|}
\hline Personalized learning technology & $\begin{array}{l}\text { I systematically use } \\
\text { the technology }(\%)\end{array}$ & $\begin{array}{l}\text { I use some of the } \\
\text { elements of the } \\
\text { technology }(\%)\end{array}$ & $\begin{array}{c}\text { I do not know how } \\
\text { to apply it } \\
(\%)\end{array}$ & $\begin{array}{c}\text { I have never heard } \\
\text { of this technology } \\
(\%)\end{array}$ & $\begin{array}{c}\text { I reject this } \\
\text { technology } \\
(\%)\end{array}$ \\
\hline $\begin{array}{l}\text { Technology of development of the } \\
\text { individual cognitive learning style }\end{array}$ & 30.88 & 60.29 & 8.53 & 0 & 0 \\
\hline Level differentiation technology & 64.71 & 32.35 & 1.47 & 0 & 1.47 \\
\hline Multi-level task technology & 26.09 & 47.80 & 24.64 & 0 & 1.47 \\
\hline Case problem technology & 57.35 & 25.00 & 16.18 & 0 & 1.47 \\
\hline Visualization technology & 23.88 & 38.81 & 31.34 & 0 & 5.97 \\
\hline Style differentiation technology & 22.06 & 32.35 & 44.12 & 0 & 1.47 \\
\hline
\end{tabular}

learning challenge that promotes interhemispheric interaction and activation of other sensory channels. The cognitive skills are developed at this stage.

4. The final psychological and pedagogical diagnostics is carried out. A new matrix of internal resources is drawn up. The results and prospects in regard to cognitive skills development are defined by comparing the matrices.

\section{RESULTS}

\section{The Empirical Data about the Use of Personalized Learning Technologies by Russian Teachers}

The study "Psychological Comfort in Education in Modern Rural School" conducted by (Korshunova \& Baiborodova, 2020) started on 1 October 2019 and will continue up to 30 December 2020. 592 teachers from ten regions of the Russian Federation (Nizhny Novgorod, Ivanovo, Vologda, Kirov, Kostroma, Yaroslavl regions; Krasnoyarsk Krai, Perm Krai, and the Republics of Karelia and Dagestan) have been surveyed. The obtained data demonstrate whether the surveyed teachers know of and use the personalized learning technologies in their teaching practices (public access link to the results by regions: https://clck.ru/McpuD). As for the level differentiation technology, the teachers show quite a high performance level (the mean value by regions of the indicator for systematic use of the technology and use of its elements is close to $100 \%)$. The mean value of the indicator for the technology of development of the individual cognitive learning style is lower (about $80 \%$, the most part of it is the answer: I use some of the elements of the technology); a larger proportion of teachers state that they do not know how to apply this technology (about 17\%) or they have never heard of it (about 14\%). The multi-level task technology is considered to be a special case of the level differentiation technology; however, teachers state that they cannot apply this technology more often in comparison with the level differentiation technology (13 to $29 \%$ ). The performance level for this technology can be considered as medium with a high proportion of those who do not know how to apply this technology (25 to $44 \%$ ). About $70 \%$ of the respondents can design and use case problems which are supposed to involve activity based learning in the form of competence- oriented tasks. The style differentiation technology as a system and its elements are used by $50 \%$ of the teachers; another 50\% do not know how to apply it. Quite a large proportion of teachers (5 to $31 \%$ ) choose the answer "I do not know how to apply it" in respect of the case problem technology as well. The teacher survey results in Kirov Region are presented in Table 2.

The teaching teams of experimental schools participated in designing a course and a series of practical seminars on personalized learning technologies. The survey data was used in the preparatory work.

The teachers applied the acquired skills and knowledge in teaching mathematics to 5-7 graders. Psychological diagnostics was carried out together with psychologists to determine the dominant hemisphere and the perceptual learning styles of schoolchildren; verbal logical reasoning was tested; the level of general learning skills was determined. A matrix of internal resources was drawn up for each grade; it contained the necessary data on each learner. Below is an example of the matrix of internal resources based on the summarized results of psychological and pedagogical diagnostics and expert observation for one of the schools participating in the experiment (Kirov secondary school No.56) (Table 3). The data obtained are the basis for the formative stage of the experiment which is currently going on.

\section{The Classification of Teaching Techniques to Develop Cognitive Skills Based on the Perceptual Learning Style and the "Type of Learning in Accordance with the Dominant Hemisphere" Criterion}

Table 4 describes a set of instructional techniques grouped on the basis of the "type of learning in accordance with the dominant hemisphere" criterion. They are aimed at developing the cognitive skills of schoolchildren taking into account the perceptual learning style. They can be used in teaching mathematics to create situations of successful learning and promote learners' development (The notations used in Table 4: A - auditory learner, V - visual learner, K - kinesthetic learner). 
Table 3. The summarized results of psychological and pedagogical diagnostics in the experimental school

\begin{tabular}{|c|c|c|c|c|c|c|c|c|}
\hline \multirow{2}{*}{ Grade } & \multicolumn{2}{|c|}{ Dominant hemisphere } & \multicolumn{3}{|c|}{ Learning style (modality) } & \multicolumn{3}{|c|}{ Level of cognitive skills } \\
\hline & left & right & $\mathrm{V}$ & $\mathrm{A}$ & $\mathrm{K}$ & general learning skills & logical reasoning skills & problem solving skills \\
\hline \multirow{3}{*}{5} & \multirow{3}{*}{$59 \%$} & \multirow{3}{*}{$41 \%$} & \multirow{3}{*}{$30 \%$} & \multirow{3}{*}{$51 \%$} & \multirow{3}{*}{$19 \%$} & low $18 \%$ & low $21 \%$ & low $31 \%$ \\
\hline & & & & & & base $74 \%$ & base $67 \%$ & base $59 \%$ \\
\hline & & & & & & high $8 \%$ & high $12 \%$ & high $10 \%$ \\
\hline \multirow{3}{*}{6} & \multirow{3}{*}{$61 \%$} & \multirow{3}{*}{$39 \%$} & \multirow{3}{*}{$19 \%$} & \multirow{3}{*}{$44 \%$} & \multirow{3}{*}{$37 \%$} & low $17 \%$ & low $34 \%$ & low $33 \%$ \\
\hline & & & & & & base $51 \%$ & base $41 \%$ & base $38 \%$ \\
\hline & & & & & & high $32 \%$ & high $25 \%$ & high $29 \%$ \\
\hline \multirow{3}{*}{7} & \multirow{3}{*}{$63 \%$} & \multirow{3}{*}{$37 \%$} & \multirow{3}{*}{$33 \%$} & \multirow{3}{*}{$54 \%$} & \multirow{3}{*}{$13 \%$} & low $18 \%$ & low $21 \%$ & low $26 \%$ \\
\hline & & & & & & base $54 \%$ & base $52 \%$ & base $51 \%$ \\
\hline & & & & & & high $28 \%$ & high $27 \%$ & high $23 \%$ \\
\hline
\end{tabular}

Table 4. Teaching techniques grouped in accordance with the dominant hemisphere and modality

Modality Cognitive skills Teaching techniques

Right brain dominant learning

V general learning "Case tasks based on historical facts". A case task consists of a small text and a few tasks for the text, its subject and

A skills meta-subject content. A historical text will allow addressing both mathematics-related problems and also culturalhistorical, philosophical, psychological, spiritual and moral aspects (Klepikov, 2018). The task can be associated

problem solving with the history of mathematics, culture and history of the native land, folklore. Such content will help to create a

skills vivid image in the learner's imagination. For example, studying irrational numbers, one can give a text with a narrative about the cultural and historical realities associated with how these numbers appeared which will

logical reasoning demonstrate the need for a balance between the "rational" and the "irrational" in the world around. The text can be skills given for students to read independently, or it can be read by the teacher in class. This way, different sensory channels are involved. The text can be accompanied with a picture, am image, or a comic strip.

The tasks based on the text can vary: to find explicit or implicit, main or secondary information, to make up questions, to draw up a classification, to express one's attitude to the information, make a plan for the text, come up with a title, etc. Tasks based on the subject are tasks that are directly related to the text and the subject and make the students apply the solution algorithms that they have learned.

For example (Koroshchenko et al., 2015): What century did these events happen? a) The ancestors of modern Mansi and Khanty inhabited the North, and in 840 AD part of these tribes moved west and settled on the banks of the Danube. They were ancestors of the Hungarians. b) the first mention of Siberia, of Ugric and Samoyedic peoples is found in the Russian manuscript of 1096 called The Tale of Bygone Years; c) Yermak (Vasily Alenin) set out on a campaign on 1 September 1581. d) Yugra (Siberia) was treated as a Novgorod volost starting from 1265. e) Tobolsk Museum opened in 1887. f) The construction of the stone Tobolsk Kremlin started in 1700.

$\mathrm{V} \quad$ problem solving "Fantastic elements" The teacher brings elements of fiction to a standard task: a trip to a fairy tale, an uninhabited skills island, a well-known film, a picture. Students have to come up with a solution and draw it.

K problem solving "Animation" A student or a group of students choose roles and necessary accessories from those offered by the skills teacher. For example, the assignment is to animate a task for movement, to illustrate a task for fractions with the available material.

A problem solving "Music anchor" The task is to choose the melody best suited for the process of solving a particular mathematics skills task. This way the problem solving process will be associated with a particular melody.

A general learning "Prequel/ sequel" Students are offered to invent and tell, or write/draw what happened before or will happen skills after the story described in the task given by the teacher. They come up with changes that may be introduced into the situation described in the task.

A general learning "My story" Students are asked to make their own cinquain, puzzle, or story using the key words of the lesson skills (math terms/concepts) then read their piece of work aloud with expression.

Cinquain plan:

First line. 1 word - concept or topic (noun).

Second line. 2 words - description of the concept (adjective).

Third line. 3 words - actions (verbs).

Fourth line. A word combination or sentence, associated with the topic (aphorism)

Fifth line. 1 word - a synonym that refers to the topic.

$\mathrm{V} \quad$ general learning “What is happening?" Students are given an image or a task pattern/scheme; they are asked to explain what is skills happening. What was happening/happened before? What may happen afterwards? Are there any inconsistencies in the image? They are asked to solve the task according to the scheme.

A general learning "Brainstorming" Students are asked to offer their hypotheses and ideas in respect to the topic of a lesson, a problem skills or a task. Any even the most fantastic and unexpected ideas are accepted. Everybody's opinion counts.

V logical reasoning "Visual testing" Working out classifications, choosing the right option, multiple choice tasks, sequence restoration, skills sorting out a problem making maximum use of the visual material.

$\mathrm{V} \quad$ logical reasoning "Math dominos" The cards are prepared according to the dominos principle: each end of a card is the answer

$\mathrm{K}$ skills (supplement) to another card. Formulas, symbols, drawings can be used. There can be a computer and paper versions.

"Math carpet" Square cards are prepared containing answers on each side. It is necessary to combine the cards so that the two sides next to each other make a pair, creating a carpet in this way.

The students can be involved to create the dominoes and carpet cards.

$\mathrm{V} \quad$ problem solving “Internet meme" Explain a popular Internet meme or comics related to mathematics. Make your own meme related skills to the topic of the lesson.

$\mathrm{V} \quad$ general learning "Images of color, symbol, action" Artists, poets, musicians perceive the surrounding objects and information

K skills through color, actions, or symbols. Students can be asked to offer color or action associated with a mathematical operation, term, etc. The color or action can be used every time they work with these operations or terms. 
Table 4 (continued). Teaching techniques grouped in accordance with the dominant hemisphere and modality

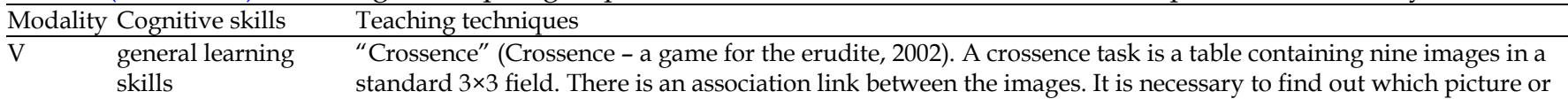

logical reasoning skills word should be located in field 5 . There are a few ways to solve the crossence task (Figure 1):

\begin{tabular}{|c|c|c|}
\hline 1 & 2 & 3 \\
\hline 4 & 75 & 6 \\
\hline 7 & 8 & 9 \\
\hline
\end{tabular}

\begin{tabular}{|c|c|c|}
\hline 1 & 2 & $x^{3}$ \\
\hline $4 \rightarrow$ & 5 & $\leftarrow 6$ \\
\hline $7^{\star}$ & $\stackrel{4}{4}$ & $\star$ \\
\hline
\end{tabular}

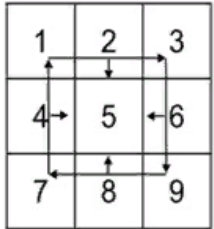

Figure 1. Crossence solution options

\begin{tabular}{|c|c|c|}
\hline $\begin{array}{ll}\mathrm{V} \\
\mathrm{K}\end{array}$ & $\begin{array}{l}\text { logical reasoning } \\
\text { skills }\end{array}$ & $\begin{array}{l}\text { "Links" Some of the arrows demonstrating connection between elements of a picture, diagram or mind map are } \\
\text { missing. It is necessary to reestablish them. }\end{array}$ \\
\hline $\mathrm{V}$ & $\begin{array}{l}\text { general learning } \\
\text { skills }\end{array}$ & $\begin{array}{l}\text { "Correction task" Students are asked to find all the terms on the topic hidden in a sequence of letters and give a } \\
\text { definition for these terms. } \\
\text { Task: Find the hidden words which are the terms of today's topic; find the odd one out: } \\
\text { fgtymspeeddepnwayweedstrajectorycoveretimehypisecond } \\
\text { Answer: speed, way, trajectory, time, second }\end{array}$ \\
\hline $\bar{A}$ & $\begin{array}{l}\text { general learning } \\
\text { skills }\end{array}$ & $\begin{array}{l}\text { «Letter dictation». It is designed to test if students know the new terminology. The teacher dictates a set of } \\
\text { questions; students listen to the task, do it mentally and write down the answer. The questions are not usual, it } \\
\text { is necessary to identify specific letters. Then the letters are used to create a word that is a math term. } \\
\text { For example: Answer the questions: } \\
\text { 1. The fifth letter in the term for numbers } 1,2,3,4,5,6,7,8,9,10,11,12 \text {, etc., which are used for counting } \\
\text { things. (natural) - } \mathrm{r} \\
\text { 2. The third letter in the term for a ratio of two expressions or numbers other than zero. (fraction) - a } \\
\text { 3. The third letter in the term for a section of a curve, graph, or geometric figure. (arc) - c } \\
\text { Answer: rac } \\
\text { Word: arc } \\
\text { One more dictation option is to use the letter-to-number cipher; in this case students are asked to decode a } \\
\text { series of numbers. }\end{array}$ \\
\hline $\begin{array}{l}\mathrm{V} \\
\mathrm{K}\end{array}$ & $\begin{array}{l}\text { problem solving } \\
\text { skills }\end{array}$ & $\begin{array}{l}\text { "Math coloring" Math coloring is an image that must be painted according to certain rules. To find out the } \\
\text { necessary color, a student has to do calculations. The teacher has to prepare an image, an illustrative example, } \\
\text { and the rules: color-action. }\end{array}$ \\
\hline
\end{tabular}

$\mathrm{V} \quad$ logical reasoning "Associations" Students use their own experience to put forward and substantiate a hypothesis. There are A skills different variants of this task:

- concepts: the teacher writes down the main concept, then asks the students to name the features of this concept or give associations. There may be an extra condition: words must have the same root or letters as the main concept;

- a flower: the teacher draws a flower (or lays out a pre-prepared one): the middle and the petals, then asks the students to describe properties and characteristics of the concept and writes them down on the petals;

- a house: the teacher draws a rectangle and writes the main concept on its top, students are asked to give synonyms, antonyms, adjectives, verbs that are associated with this concept, all the components are located at different levels, the main word is on the top /"roof";

\begin{tabular}{ll}
\hline Left brain dominant learning \\
\hline $\mathrm{A}$ & general learning \\
$\mathrm{V}$ & skills \\
$\mathrm{K}$ & $\begin{array}{l}\text { logical reasoning } \\
\text { skills }\end{array}$ \\
& $\begin{array}{l}\text { logical reasoning } \\
\text { skills }\end{array}$
\end{tabular}

"Draw up an algorithm or action plan" Students are given key phrases and they are asked to restore the plan, algorithm, story about the function, etc. Then do a task according to the plan.

logical reasoning

"Schulte tables" Students can be given a task with one table: For example, find all the numbers in the order of increasing and determine the difference between the numbers. The performance time can be limited.

\begin{tabular}{|c|c|c|c|}
\hline 2 & 26 & 20 & 8 \\
\hline 12 & 32 & 4 & 14 \\
\hline 18 & 22 & 10 & 24 \\
\hline 6 & 30 & 16 & 28 \\
\hline
\end{tabular}

Figure 2. One-table version of Schulte tables

A task with two tables. Comparing the two tables, it is necessary to find out a math term or concept. In a more complex version, you can encrypt a phrase: axiom, part of a theorem, rule.

\begin{tabular}{|l|l|l|}
\hline 1 & 9 & 4 \\
\hline 7 & 3 & 8 \\
\hline 5 & 2 & 6 \\
\hline
\end{tabular}

\begin{tabular}{|c|c|c|}
\hline $\mathrm{h}$ & $\mathrm{a}$ & $\mathrm{e}$ \\
\hline $\mathrm{o}$ & $\mathrm{p}$ & $\mathrm{l}$ \\
\hline $\mathrm{r}$ & $\mathrm{y}$ & $\mathrm{b}$ \\
\hline
\end{tabular}

Figure 3. Two-table version of Schulte tables Answer: hyperbola 
Table 4 (continued). Teaching techniques grouped in accordance with the dominant hemisphere and modality

Modality Cognitive skills Teaching techniques

A general learning "Reading with pauses" Students are given a task; the text in the task is divided into semantic parts. The notes in the skills text show where students should stop reading, make up questions, answer them, do some additional tasks, and then continue reading.

Further, students can choose themselves when and where to stop reading.

V general learning "Word cloud" represents a lot of words written in a specific form (picture): cloud, apple, emoji symbol, etc. The task skills is to study the picture carefully for 15-20 seconds and try to remember as many words as possible.

Added complexity: Find and remember only the terms related to the topic, so unnecessary terms are included in the picture. Students can be asked to give a definition to the terms, explain why some words are odd ones. This technique is effective at different stages of the lesson; it helps to train memory.

A general learning "Number dictation"

$\mathrm{V} \quad$ skills $\quad$ "answering in writing" - to answer the questions in writing (yes - 1, no - 0 ) with mistakes correction taking place later.

"signal cards" - answer options are indicated with colors, the students have on their desks cards of 2 - 3 colors, to answer, they choose a card of specific colour depending on the question.

A logical reasoning "Chain" Students read a text, make up questions and answers for the text. The first question is asked by the teacher, skills any of the students answers it. Then this student asks another question and checks if the answer given by classmates is correct, etc.

$\mathrm{V} \quad$ general learning "Gapped text" Students may be given correct and extra word to complete this task. They are asked to fill in the skills gaps to get a logical text.

Balanced hemisphere learning

$\mathrm{V} \quad$ general learning "Mind maps" (Buzan, 2007) The core concept is located in the center of a diagram and all new words, phrases and $\mathrm{K}$ skills concepts associated with it are organized around it. A paragraph in the textbook or a text prepared by a teacher can problem solving be used as a source for creating a mind map (Pushkaryeva, 2011).

skills

logical reasoning skills

V general learning

problem solving st skills

logical reasoning skills

"Logical-semantic model" (Steinberg \& Manko, 2005). A multidimensional model helps to visualize different data statements, and the nodes show the semantic connections between them.

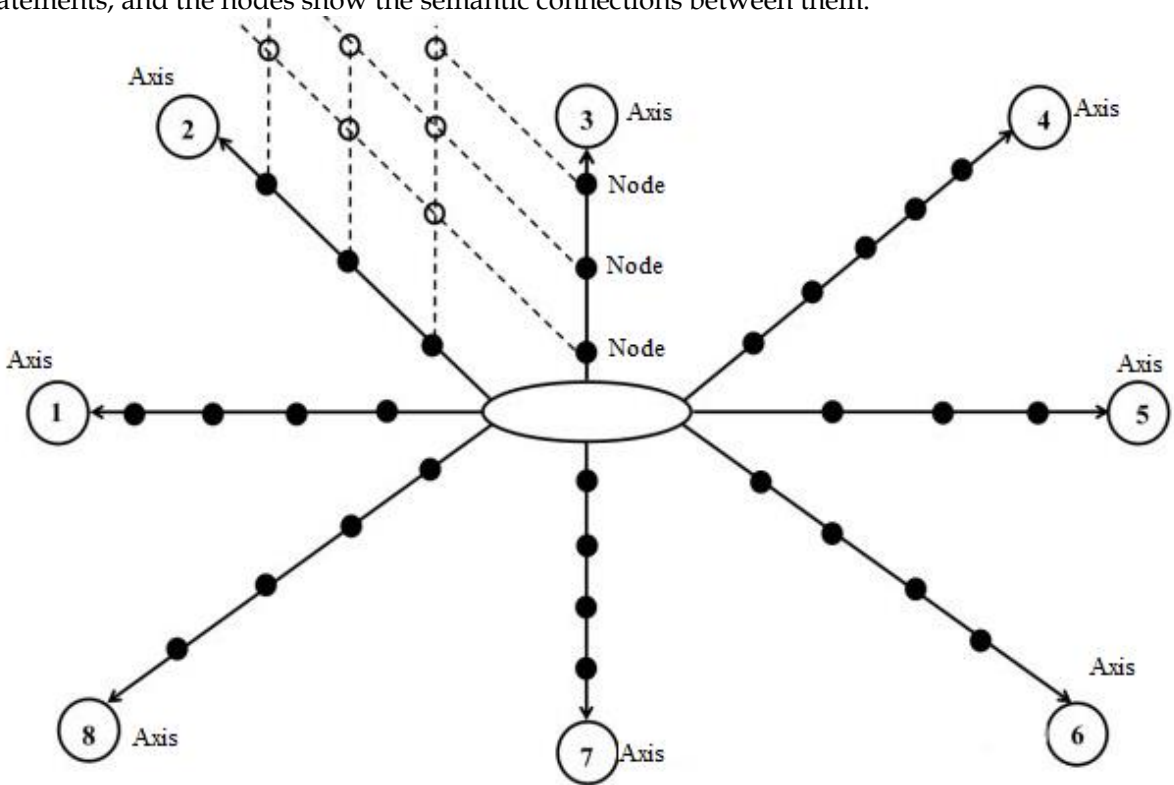

Figure 4. Generalized graph for a logical-semantic model

\section{Criteria for Assessing the Development of Cognitive Skills on the Basis of the Perceptual Learning Style}

There are three levels of cognitive skills which consist of general learning skills, logical operations, and problem solving skills: low, base, and high (Table 5). The criteria described below can help to describe the dynamics of development of cognitive skills at the formative stage of the ongoing experiment.

\section{DISCUSSIONS}

The studies conducted by and Gazzaniga and Sperry (1967) showed that the left and right brain hemispheres have different functions and process information differently. Further experiments by Posner and Raichle (1994), Dehaene (1996) demonstrated that different sides of the brain can be involved in problem solving depending on the task and its solution options. These data became the basis for development of educational technologies which take into account individual 
Table 5. Levels of cognitive skills

\begin{tabular}{|c|c|c|c|}
\hline Level & General learning skills & Logical operations & Problem solving skills \\
\hline low & $\begin{array}{l}\text { partially understands the content of the } \\
\text { source of information; experiences difficulties } \\
\text { trying to find the necessary information in the } \\
\text { source; makes mistakes when retrieving } \\
\text { information; works in a non-systematic } \\
\text { fashion; turns to the teacher for detailed } \\
\text { explanation }\end{array}$ & $\begin{array}{l}\text { can single out only some } \\
\text { characteristics of the object; makes } \\
\text { mistakes in analysis and synthesis, in } \\
\text { drawing up classification; makes } \\
\text { mistakes when determining causes } \\
\text { and consequences; fails to put forward } \\
\text { and substantiate a hypothesis }\end{array}$ & $\begin{array}{l}\text { fails to independently identify a } \\
\text { contradiction or a problem in the source, } \\
\text { fails to state a problem }\end{array}$ \\
\hline base & $\begin{array}{l}\text { can partially find the necessary information, } \\
\text { convert it from one kind to another, can use } \\
\text { sign schemes and models to represent the } \\
\text { task; formulates a cognitive task on the basis } \\
\text { of the source; turns to the teacher for some } \\
\text { clarification }\end{array}$ & $\begin{array}{l}\text { makes mistakes in defining the } \\
\text { characteristics of the object, in analysis } \\
\text { and synthesis, in drawing up } \\
\text { classification; partially determines } \\
\text { causes and consequences; can offer a } \\
\text { hypothesis but fails to substantiate it }\end{array}$ & $\begin{array}{l}\text { can independently identify a } \\
\text { contradiction, state a problem; uses } \\
\text { algorithms to solve the task following } \\
\text { the example given }\end{array}$ \\
\hline high & $\begin{array}{l}\text { can find all the necessary information given in } \\
\text { the source in explicit and implicit forms; can } \\
\text { independently convert information from one } \\
\text { kind to another involving symbolic modeling; } \\
\text { uses additional sources of information; works } \\
\text { independently }\end{array}$ & $\begin{array}{l}\text { can single out all the characteristics of } \\
\text { the object; independently carries out } \\
\text { analysis and synthesis, draws up } \\
\text { classification; can determine the } \\
\text { causes and consequences; can put } \\
\text { forward and substantiate a hypothesis }\end{array}$ & $\begin{array}{l}\text { can independently state a problem in a } \\
\text { clear manner; has several solution } \\
\text { options and chooses a specific way to } \\
\text { solve the problem; can explain the } \\
\text { choice of a particular solution; } \\
\text { demonstrates a creative approach to } \\
\text { problem solving }\end{array}$ \\
\hline
\end{tabular}

characteristics of students - these are personalized learning technologies. It was assumed that if one took into account the dominant hemisphere and the perceptual learning style (Barbe \& Michael, 1981; Fleming \& Baume, 2006), it would be easier for students to master cognitive and other skills. R. Dunn and K. Dunn (1993) substantiated the idea that awareness of their own learning style allows students to choose more effective learning strategies, and it allows teachers to modify instructional strategies and better understand their students; learners are expected to demonstrate higher level of "learnability" and memory for the material presented in their preferred modality. Thus, a new science called neuropedagogy appeared in the 90s of the 20th century incorporating neurophysiology, psychology, and pedagogy findings. There were also opponents of the idea of strict separation of the functions of right and left hemispheres, for instance, Bruer (1997) who did not consider it beneficial for teaching practice. Goel (2015) argues that it is necessary to develop both sides of the brain and interhemispheric interaction to successfully resolve problems and contradictions in real life. This is the main idea of the dynamic balance concept.

The idea of taking into account neuropsychological characteristics of the learner (the dominant brain hemisphere and the perceptual learning style) has its supporters as well as it allows creating conditions for more effective and successful learning and development of schoolchildren. However, psychologists and educators suggest that interhemispheric interaction, motivational and emotional factors facilitate development of cognitive skills (Khrizman \& Zaitseva, 1981; Kraitzig \& Arbuthnott, 2006). We support this approach.

\section{CONCLUSION}

The study findings suggest that teachers experience certain difficulties applying personalized learning technologies, which determines the need for systematic work in this field. The teacher teams of experimental schools participated in different activities to master the technologies and teaching methods. The teachers now implement the acquired skills and knowledge in teaching mathematics to 5-7 graders. We believe that a teacher should employ the knowledge about the dominant brain hemisphere and the perceptual learning styles of his/her students in mathematics teaching. A mathematics teacher should follow the following stages to successfully develop cognitive skills of schoolchildren: to carry out the psychological and pedagogical diagnostics and expert observation; to build a matrix of internal resources of schoolchildren; to assess the psychological and pedagogical potential of educational activities taking into account the identified internal resources and identify the learning activities, teaching methods and techniques which correspond to the proffered learning style and the ones which may present a challenge: they will optimize interhemispheric interaction and development of other sensory channels; to apply the selected components of the didactic system in mathematics teaching; to carry out the psychological and pedagogical diagnostics again and build a new matrix of internal resources. When students learn in their preferred modality, the teacher creates the orientation basis for the formation of cognitive skills which students will develop, master and assess independently. The cognitive skills are developed when learners perform more challenging activities. This way the teacher creates the conditions for enhancing interhemispheric interaction and facilitating the development of all sensory channels, which means that the dynamic balance is maintained; thus, development of cognitive skills in 
mathematics learning is based on the perceptual learning style reflecting the specifics of the interhemispheric interaction of students.

The classification of teaching techniques based on the leaning style has been worked out and presented in the article; it can be used by teachers to develop cognitive skills of students. The classification is based on the criteria of "type of learning in accordance with the dominant hemisphere". The techniques can be used in mathematics teaching to create situations of successful learning and development.

The direction for future research is assessment of the level of cognitive skills by means of the tools we have identified and described in this study as part of the ongoing formative stage of the psychological and pedagogical experiment.

\section{ACKNOWLEDGEMENTS}

1. The work is performed according to the Russian Government Program of Competitive Growth of Kazan Federal University.

2. The work is performed according to the project of improving competitiveness of the leading Russian universities among the leading world scientific education centers "5-100" of First Moscow State Medical University

3. The work is performed according to the Program of Development of Financial University under the Government of the Russian Federation for 2020.

\section{REFERENCES}

Akishina, E. M., Sudakova, Y. E., Prokopyev, A. I., Yakubenko, K. Y., Solovyeva, N. A., \& Korzhuev, A. V. (2017). System of cultural experience development of humanities students in modern information media conditions. Man in India, 97(14), 115-127.

Ananyev, B. G. (1968). Structure of individual development as a problem of modern pedagogical anthropology. Sov. Pedagogy, 1(2), 21-31.

Asmolov, A. G., Burmenskaya, G. V., Volodarskaya, I. A., Karabanova, O. A., Molchanov, S. V., \& Salmina, N. G. (2011). Program of development of universal educational actions in high school. National Psychological Journal, 1(5), 104-110.

Avdeev, V. A., Avdeeva, O. A., Shagieva, R. V., Smirnova, V. V., Mashkin, N. A., \& Taradonov, S. V. (2019). The mechanism of legal regulation in the conditions of globalization and formation of information environment. Regional aspect. Journal of Environmental Management and Tourism, 10(7), 1517-152

Barbe, W. B., \& Michael, N. (1981). What we know about modality strengths. Educational Leadership.
Association for Supervision and Curriculum Development. $\quad$ Retrieved from http://www.ascd.org/ASCD/pdf/journals/ed_le ad/el_198102_barbe.pdf

Bruer, J. T. (1997). Education and the brain: a bridge too far. Educ. Res., 26, 4-16. https://doi.org/10.3102/ 0013189X026008004

Buzan, T. (2007). Mind Mapping: unique technique of storing information. Moscow: Rosman.

Byrnes, J. P., \& Fox, N. A. (1998). The Educational Relevance of Research in Cognitive Neuroscience. Educational Psychology Review, 10(3), 297-342. https:/ / doi.org/10.1023/A:1022145812276

Cherdymova, E. I., Afanasjeva, S. A., Parkhomenko, A. G., Ponyavina, M. B., Yulova, E. S., Nesmeianova, I. A., \& Skutelnik, O. A. (2018). Student ecological consciousness as determining component of ecological-oriented activity. EurAsian Journal of BioSciences, 12(2), 167-174.

Crossence - a game for the erudite. (2002). Science and life. Retrieved from https://www.nkj.ru/archive/ articles/5105/

Dalinger, V. A. (2020). Peculiarities of cognitive-visual technology of teaching mathematics in secondary schools. Trends in the development of science and education, 7(58), 36-46. Retrieved from https:/ / www.elibrary.ru/download/elibrary_42497756_96124246.pdf

Danyushenkov, V. S., \& Korshunova, O. V. (2013). The study of cognitive activity of students by computer encephalography. Pedagogy and Psychology, 1, 150157. Retrieved from https://elibrary.ru/ download/elibra-ry_20313363_13089578.pdf

Dehaene, S. (1996). The organization of brain activations in number comparison. Journal of cognitive neuroscience, 8(1), 47-68. https://doi.org/10.1162/ jocn.1996.8.1.47

Dunn, R. (1983). Learning style and its relation to exceptionality at both ends of the spectrum. Exceptional Children 49, 496-506. https://doi.org/ $10.1177 / 001440298304900602$

Dunn, R., \& Dunn, K. (1993). Teaching Secondary School Students Through Their Individual Learning Styles: Practical Approaches for Grades. Boston: Allyn \& Bacon.

Ellerman, J. S., \& Kleiner, B. H. (1996). How to establish rapport with others. Managing Serv. Quality, 6(3), 3942. https:/ / doi.org/10.1108/09604529610115876

Eremeeva, V. D. (2010). The theory and practice of differentive education. Bulletin of the practical psychology of education, 3, 115-123. Retrieved from https:/ / psyjournals.ru/files/47630/vestnik_psyo br_2011_1_Eremeeva.pdf 
Firsova, I., Vasbieva, D., Prokopyev, A. I., Zykin, E. S., \& Matvienko, V. V. (2018). Development of consumers' behavior business model on energy market. International Journal of Energy Economics and Policy, 8(4), 227-233.

Fleming, N., \& Baume, D. (2006). Learning Styles Again: VARKing up the right tree! Educational Developments. Retrieved from http://www.vark-learn.com/wpcontent/uploads/2014/08/EducationalDevelopments.pdf

Galeyeva, N. L., \& Morgacheva E. V. (2015). Features of the maintenance of competences of the elementary school teacher realizing the individual approach in training pedagogics. Psychology: selected papers of the international scientific school "paradigma". Yelm, pp. 20-33.

Galperin, P. Ya. (2010). On Development of Mental Actions and Concepts. Kul'turno-istoricheskaya psikhologiya. Cultural-Historical Psychology, 6(3), 111-114. Retrieved from https://psyjournals.ru/ kip/2010/n3/30843.shtml

Gazzaniga, M. S., \& Sperry, R. W. (1967). Language after section of the cerebral commissures Brain. Journal of neurology, 90(1), 131-148. https://doi.org/10.1093/ brain/90.1.131

Gimaliev, V. G., Prokopyev, A. I., Makarova, E. V., Abdulkhakova, K. R., Kozin, M. N., \& Fazylzyanova, G. I. (2018). Personality features and values orientations of university students with manipulative behaviour. Espacios, 39(20), 14.

Goel, V. (2007). Anatomy of deductive reasoning. Trends in Cognitive Sciences, 11(10), 435-441. https:/ / doi.org/10.1016/j.tics.2007.09.003

Goel, V. (2015). Indeterminacy tolerance as a basis of hemispheric asymmetry within prefrontal cortex. Frontiers in Human Neuroscience, 9. https:/ / doi.org/10.3389/fnhum.2015.00326

Khairullina, E. R., Bogdanova, V. I., Slepneva, E. V., Nizamutdinova, G. F., Fatkhullina, L. R., Kovalenko, Y. A., \& Skutelnik, O. A. (2019). Global climate change: Cyclical nature of natural and permanent nature of man-made processes. EurAsian Journal of BioSciences, 13(2), 2311-2316.

Khrizman, T. P., \& Zaitseva, L. M. (1981). Role of neocortical Association Structures In The Spatiotemporal Organization Of Brain Potentials In Children During Perception Of Sensory Stimuli Of Different Modalities. Neuroscience and Behavioral Physiology, 11(2), 188-194. https://doi.org/ 10.1007/BF01182380

Klepikov, V. N. (2018). Cultural-Historical reconstruction of mathematical phenomena in modern school education. Journal of School Technology, 4, 129-135. Retrieved from https: / cyber leninka.ru/article/n/kulturno-istoricheskaya- rekonstruktsiya-matematicheskih-fenomenov-vsovremennom-shkolnom-obrazovanii

Koroshchenko, N. A., Kushnir, T. I., Shebanova, L. P., Yarkova, G. A., \& Demisenova, S. V. (2015). Mathematical tasks with the regional content as a means of formation of the universal educational actions in 5-6 grades. Modern problems of science and education, 4, 263-272. Retrieved from http://www. science-education.ru/ru/article/view?id=21391

Korshunova, O. V., \& Baiborodova, L. V. (2020). Psychological Comfort in Education in Modern Rural School. Retrieved from https:/ / drive.google.com/file/d/1_TjBWVB7T13 npPQ-hNL8_6v7NYlofijr/view?usp=sharing

Kraitzig, G. P., \& Arbuthnott, K. D. (2006). Perceptual Learning Style and Learning Proficiency. A Test of the Hypothesis Journal of Educational Psychology, 98(1), 238-246. https://doi.org/10.1037/00220663.98.1.238

Marinsek, N., Turner, B. O., Gazzaniga, M., \& Miller, M. B. (2014). Divergent hemispheric reasoning strategies: reducing uncertainty versus resolving inconsistency. Front. Hum. Neurosci, 8, 839-846. https://doi.org/10.3389/fnhum.2014.00839

Mutavchi, E. P., Prokopyev, A. I., Kostyleva, G. V., Blinov, L. V., Fedorov, V. V., \& Polichka, A. E. (2018). Scientific - methodical resource of student training and vocational motivation development in university. Espacios, 39(20), 15.

OECD. (2015). Table D4.3. See Source for more information and Annex 3 for notes. Retrieved from www.oecd.org/education/education-at-aglance19991487.htm

Order of Ministry of Labor and Social Protection. (2013). Order of Ministry of Labor and Social Protection of the Russian Federation no. 544n of 18.10.2013 “On approval the professional standard for teacher" (amended and revised). Retrieved from http:/ / www.consultant.ru/

Ovsyanik, A. I., Sidorenko, G. G., Prasolov, V. I., Aleksandrova, N. S., Mashkin, N. A., Pozdnyakova, I. R., \& Makarova, E. V. (2020). Remote education in modern university: Potential opportunities, quality or availability? International Journal of Psychosocial Rehabilitation, 24(4), 5027-5034. https://doi.org/ 10.37200/IJPR/V24I4/PR201602

Pobokin, P. A. (2014). Virtual and visual thinking in mathematics. Bulletin of the Cherepovets State University, 6(59), 317-329. Retrieved from https:/ / cyberleninka.ru/article/n/virtualnoe-ivizualnoe-myshleniya-na-urokah-matematiki

Posner, M., \& Raichle, M. (1994). Images of mind. New York: Scientific American Library.

Prado, J., \& Novek, I. (2007). Overcoming perceptual features in logical reasoning: parametric functional 
magnetic resonance imaging study. Journal of Cognitive Neuroscience, 19(4), 642-657. https:// doi.org/10.1162/jocn.2007.19.4.642

Preiss, G. (1992). Ein System zur Simulation natürlicher Neuronennetze mit Beiträgen zum Aufbau einer Neurodidaktik. Zentralblatt für Didaktik der Mathematik, 24(3), 95-115.

Preiss, G. (1996). Neurodidaktik. Theoretische und praktische Beiträge. Pfaffenweiler: CentaurusVerl.-Ges.

Pushkaryeva, T. P. (2011). The knowledge cards application for systematization of mathematical information. The world of science, culture and education, 2, 234-246. Retrieved from https:/ / cyber leninka.ru/article/n/primenenie-kart-znaniydlya-sistematizatsii-matematicheskoy-informatsii

Sonier, I. (1982). Holistic education: Teaching of science in the affective domain. New York: Philosophical Library.
Sperry, R. W. (1961). Cerebral Organization And Behavior. The Split Brain Behaves In Many Respects Like Two Separate Brains, Providing New Research Possibilities. Science, 133(3466), 1749-1757. https:/ / doi.org/10.1126/science.133.3466.1749

Sperry, R. W. (1975). Left brain, right brain. Saturday Review, 9, 30-33.

Steinberg, V. E., \& Manko, N. N. (2005). Methodological foundations of instrumental didactics. Retrieved from https:// cyberleninka.ru/article/n/metodolo gicheskie-osnovy-instrumentalnoy-didaktiki

Zyubina, I. A., Dzyubenko, A. I., Borisenko, V. A., Popova, O. V., \& Prokopyev, A. I. (2019). Implicit linguopragmatic strategies of speech behavior of English-speaking prosecutors. XLinguae, 12(4), 92102. https:/ / doi.org/10.18355/XL.2019.12.04.08

\section{http://www.ejmste.com}

